\title{
The availability of Piperaceae and the search for this resource by Carollia perspicillata (Linnaeus) (Chiroptera, Phyllostomidae, Carolliinae) in Parque Municipal Arthur Thomas, Londrina, Paraná, Brazil
}

\author{
Isaac Passos de Lima \& Nélio Roberto dos Reis
}

Departamento de Biologia Animal e Vegetal, Universidade Estadual de Londrina. 86051-990 Londrina, Paraná, Brasil. E-mail: lima_isaac@ig.com.br

\begin{abstract}
A study about the species of Piperaceae that are consumed by a colony of Carollia perspicillata (Linnaeus, 1758) in Parque Municipal Arthur Thomas (82,72 ha) was carried out. Five available species of Piperaceae were found in the park: Piper aduncum Linnaeus, Piper amalago (Jacq.) Yuncker, Piper crassinervium H.B.K., Piper gaudichaudianum Kunth and Piper sp. C. perspicillata fed on all of these species. During the spring, the most abundant item was $P$. amalago, but the consumption of $P$. aduncum was the highest. At the beginning of the summer, $P$. crassinervium was the most abundant and most consumed item. At the end of the summer and during the fall, $P$. gaudichaudianum was the most abundant and consumed item, even in May, when $P$. amalago was the most abundant item. During the winter, the most highly available items were $P$. aduncum, Piper sp. and $P$. amalago, and the ones that were consumed the most were Piper sp., $P$. gaudichaudianum and $P$. aduncum. The results have shown that the preferences of $C$. perspicillata in the park are related to the greater abundance or the higher energetic value of the available Piperaceae. The greater search for the most energetic and least abundant species, which happened in the spring and winter, is related to the energy gain, that is, the species searches for food that will provide a greater quantity of energy per unit of consumption; and the greater search for the most abundant item, which occurred in the summer and fall, is related to saving the energy used in the search for food.
\end{abstract}

KEY WORDS. Bats, frugivory, Piper, plant-animal interaction, seed dispersion.

RESUMO. Estudou-se quais espécies de piperáceas são consumidas por uma colônia de Carollia perspicillata (Linnaeus, 1758) localizada do Parque Municipal Arthur Thomas (82,72ha). Foram encontradas no parque: Piper aduncum Linnaeus, Piper amalago (Jacq.) Yuncker, Piper crassinervium H.B.K., Piper gaudichaudianum Kunth e Piper sp. C. perspicillata alimentou-se de todas essas espécies. Durante a primavera, o item mais abundante foi $P$. amalago, porém o mais consumido foi $P$. aduncum. No início do verão, $P$. crassinervium foi o mais abundante e o mais consumido. No final do verão e no outono, $P$. gaudichaudianum foi o mais abundante e o mais consumido, mesmo em maio, quando $P$. amalago foi o mais abundante. No inverno, os itens mais disponíveis foram $P$. aduncum, Piper sp. e $P$. amalago, e os mais consumidos, Piper sp., $P$. gaudichaudianum e $P$. aduncum. Os resultados mostraram que o maior consumo de $C$. perspicillata por infrutescências de Piper, no parque, está relacionado à maior abundância ou ao maior valor energético das infrutescências disponíveis: na primavera e no inverno, a maior procura pelas espécies mais energéticas e menos abundantes está relacionada ao ganho energético, ou seja, a espécie procura alimentos que Ihe rendam maior quantidade de energia por unidade de consumo; no verão e no outono, a maior procura pela mais abundante está relacionada à economia da energia gasta na procura do alimento.

PALAVRAS CHAVE. Dispersão de sementes, frugivoria, interação planta-animal, morcegos, Piper.

Some bat species, including Carollia perspicillata (Linnaeus, 1758), are considered possible indicators of deteriorated areas (Schulze et al. 2000, Wilson et al. 1996). According to several authors (Dinerstein 1986, Charles-Dominique 1991, Marinho-Filho 1991, MülLER \& Reis 1992, BizerRIL \& RAW 1998, Thies et al. 1998, Tavares 1999), C. perspicillata has a special preference for Piper Linnaeus, 1737 species, and ReIs et al. (2003) have suggested that its presence in a certain area would be associated to its preference for Piperaceae, whether the area is deteriorated or not. In a study about the behavior of $C$. perspicillata, THiEs et al. (1998) observed that this species uses echolocation as well as smell to find ripe Piper species infrutescences. Piper plants are pioneers, with shrub, and more rarely arboreal or herbal, characteristics. They have great importance for ecological succession and are typical of dry, humid forests and disturbed areas (Figueiredo \& Sazima 2000, Fleming 1986).

Revista Brasileira de Zoologia 21 (2): 371-377, junho 2004 
Parque Municipal Arthur Thomas (PMAT) has been widely used as a place for bat studies. Müller \& ReIs (1992) studied the sharing of resources among frugivorous species in different fragmented areas; ReIs \& Müller (1995) and ReIs et al. (2000) compared the diversity of bat species from the park to others from distinct forest fragments of the region; ReIs et al. (1998) updated the list of species found in the park and in the region, and Félix et al. (2001) analyzed the park capacity concerning the maintenance of feasible bat populations.

According to GarCIA et al. (2000), the presence of pioneering plant seeds and plants of late primary succession in bat feces reinforces the idea that bats contribute significantly to the increase of diversity in these altered areas. A better knowledge of the phenology of the species utilized by C. perspicillata as well as a study of this bat's preference in these places does not only contribute to the recovery of these environments, but also to the maintenance of feasible populations of these bats.

The aim of this study was to detect the favorite Piper species of $C$. perspicillata among the ones they consumed in Parque Municipal Arthur Thomas, considering the species of Piper available and the ones being consumed by these bats. It was also to identify the infrutescences' physio-chemical properties.

\section{MATERIALS AND METHODS}

Parque Municipal Arthur Thomas presents a subtropical and humid climate, with average annual temperature of $22^{\circ} \mathrm{C}$ and rain index of approximately $1.567 \mathrm{~mm}$ (IAPAR 2002). It is situated in the geographical coordinates $23^{\circ} 15^{\prime}-23^{\circ} 30^{\prime} \mathrm{S}$ and $51^{\circ} 15^{\prime}-51^{\circ} 00^{\prime} \mathrm{W}$. With an area of $82,72 \mathrm{ha}$, it is located in the southern region of the city of Londrina (Fig. 1) within its urban perimeter. The park is one of the ultimate sites of significant vegetation of the city. 66 ha of its total area are composed of altered primary forest and according to MАACK (2002), this formation is referred to as seasonal semi-deciduous. In spite of the urban disturbance (MURPHY 1997) in its forest portion, there are large plant species such as Aspidosperma polyneuron Müll. Arg. (peroba-rosa - Apocynaceae), Gallesia integrifolia (Spreng.) Harms (pau-d'alho - Phytolaccaceae), Cabralea canjerana (Vell.) Mart. (canjarana-Meliaceae), Cedrella fissilis Vell. (cedro-Meliaceae), Inga marginata Willd. (ingá - Leguminosae-Mimosoideae), Ficus spp. (fig trees - Moraceae), Syagrus romanzoffiana (Cham.) Glassm. (jerivá - Arecaceae), Euterpe edulis Mart. (palm tree Arecaceae) e Ocotea puberula (Rich.) Ness. (canela-gosmenta Lauraceae) (FéLIX et al. 2001). Five species of Piperaceae consumed by C. perspicillata are found in the park: Piper aduncum Linnaeus; Piper amalago (Jacq.) Yuncker; Piper crassinervium H.B. K.; Piper gaudichaudianum Kunth and Piper sp.

The identification of the Piper species utilized by the bats was done according to Gardner (1977) and Marinho-Filho (1991), through a comparison between the seeds found in the feces and the seeds from identified botanical material contained in the herbarium of Universidade Estadual de Londrina (Herbarium FUEL). The botanical material of Piper species collected

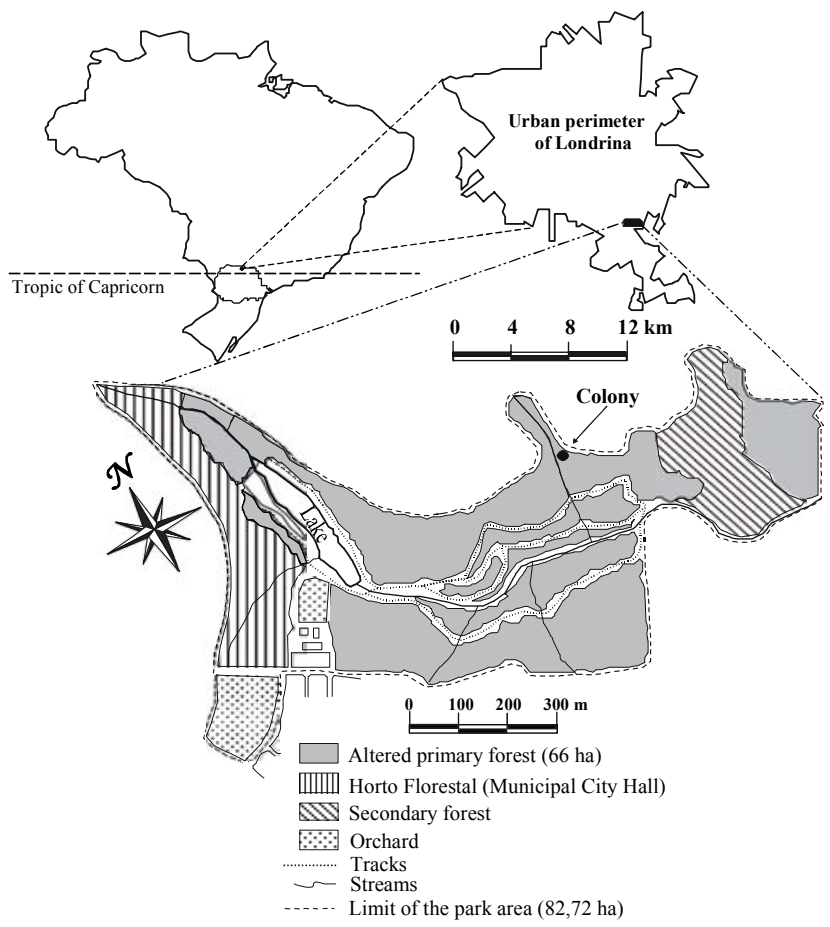

Figure 1. Location of Parque Municipal Arthur Thomas within the urban perimeter of Londrina and in detail, the location of the colony of Carollia perspicillata studied and the tracks where Piper infrutescences were collected.

from the park in this study is in the herbarium mentioned, with the collection, under the following registry number: FUEL 31763 to FUEL 31771.

In order to estimate the quantity of monthly available food in the tracks of the park, from October 2001 to September 2002, all the ripe infrutescences found along four transects measuring $100 \mathrm{~m} 2$ were counted, modified from Dinerstern (1986). The dimension of each transect was determined with the help of a $100 \mathrm{~m}$ nylon string in order to mark the edge of the track to be observed. All the Piper species which were located more than $1 \mathrm{~m}$ from the edge towards the interior of the forest were not taken into consideration. The total sampled area measured 0,04 ha. The transects were determined in different areas of several tracks of PMAT so that there would be a reliable sample of the availability of Piper species in the park. Another reason for marking the area was that in its search for food C. perspicillata may travel long distances in only one night (280-3.000m) (CHARLES-DominiQue 1991), making all the tracks in the park possible sites for the species to find food.

In order to obtain the average quantity of pulp mass (QPM) of ripe infrutescences of each species, the infrutescence mass (InfM), stem mass (StM) and seed mass (SeM) were determined. Therefore, through the equation $\mathrm{QP}=\mathrm{InfM}-(\mathrm{StM}+$ 
SeM), the quantity of pulp mass in each infrutescence was obtained (QP). The average quantity of pulp mass (QPM) and the average seed mass (ASeM) of each species of Piper were obtained through the arithmetical average of the analysed infrutescences.

If the number of ripe infrutescences found in the transects and the amount of average pulp mass of each species are known, it is possible to find the amount of infrutescence mass available, and this is how the average of available mass was determined in each unit of sampled area, through the equation

Available mass $=\mathrm{QPMInf} \times$ NRInf , where: (QPMInf) average quantity of mass pulp per infrutescence, and (NRInf) number of ripe infrutescence taken per 0,04 ha.

The feces samples containing Piper seeds taken from a colony of $C$. perspicillata, in which the number of individuals during the period of this study varied between 25 and 30, were located in a pluvial pipe in the northern area of PMAT. This pipe, whose length and diameter are $210 \mathrm{~m}$ and $1.5 \mathrm{~m}$, respectively, flows into the Pica Pau stream. In the internal part of the pipes the bats occupied several positions, establishing perches between the joints of the concrete ducts that are used to drain rainwater into the stream.

The feces samples were taken from one of these perches, located $100 \mathrm{~m}$ away from the entrance of the pipe. A newspaper was placed under the pipe, and a framework made of wood and nylon strings, measuring 1 square meter, was built to function as a basis for the newspaper. This structure was placed 70 $\mathrm{cm}$ away from the lower surface of the pipe, in order to avoid contact with humidity. During the period of collection, the newspaper was changed every day for new samples to be collected. Four monthly collections were carried out during October 2001 and September 2002. The samples were taken to a laboratory, put through nylon sieves measuring $0,3 \mathrm{~mm}$ and $0,1 \mathrm{~mm}$ under running water. The seeds were separated with the help of a stereoscopic microscope and were then dried. After being dried, their mass was determined with the use of a semi-analytic scale. Based on the average seed mass of each Piper species obtained, it was possible to estimate the average quantity of mass consumed by the bats through the seed mass found in the feces. The following formula was used Ingested mass $=\frac{\text { SeMF }}{\text { ASeMInf }} \times$ QPMInf, where: $($ SeMF) mass of seeds found in the feces, (AseMInf) average seed mass per infrutescence, and (QPMInf) average quantity of pulp mass per infrutescence.

The physio-chemical analysis of the infrutescences of each Piper species was carried in order to help the analysis of the food preferences of $C$. perspicillata, and with this aim $100 \mathrm{~g}$ of ripe infrutescences were collected from the tracks. Due to the small mass of the infrutescences, several collections were necessary so that the required amount could be obtained. The infrutescences were frozen and stored until they were sent to the laboratory of the Department of Food Technology and
Medication, at UEL (Universidade Estadual de Londrina). Under the responsibility of Professor Raúl J.H.C. Gómez and according to Instituto Adolfo Lutz (1976), the following characteristics were determined: carbohydrates, lipids (Soxleht), gross protein / total nitrogen (expressed in percentage) and the total calorific value (expressed in Kcal).

\section{RESULTS}

The five species of Piper found in Parque Municipal Arthur Thomas consumed by $C$. perspicillata are Piper aduncum, $P$. amalago, $P$. crassinervium, $P$. gaudichaudianum and Piper sp; they presented variation in availability throughout the year, which reflected on their consumption by bats (Fig. 2 and Tab. I). Piper species present, in general, infrutescences on the cob, exposed on the branch ends or directly on them, which facilitates their removal by bats during the flight (PereIra et al. 1995). Despite the fact that there are no significant differences in the average mass of the infrutescences (Tab. II), these present variations in shape and texture. Piper aduncum presents smooth infrutescences, straight when unripe and slightly curved when ripe, detaching from the leaves; Piper amalago presents wrinkled infrutescences, straight and slightly detaching from the leaves. Piper crassinervium and Piper gaudichaudianum infrutescences have a similar shape: they are slightly wrinkled, curved even when unripe, detaching from the leaves. The infrutescence with the greatest mass is Piper sp., and it is straight and wrinkled.

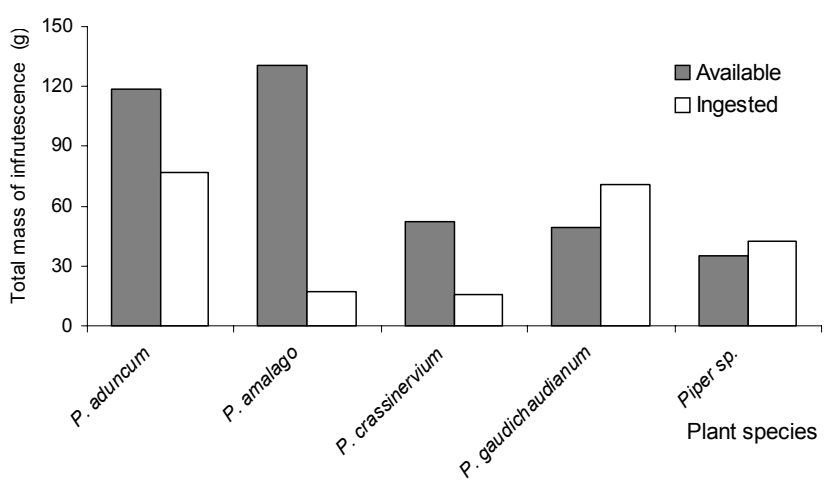

Figure 2. Total mass of Piper infrutescences available in the transects and quantity ingested throughout one year of collections (September 2001 to October 2002) in Parque Municipal Arthur Thomas.

During the spring (Fig. 3), in October and December, $P$. amalago and $P$. aduncum had the largest number of infrutescences available. Although $P$. amalago occurred in a larger amount, the search for $P$. aduncum by $C$. perspicillata was greater. In November $P$. amalago, $P$. aduncum, $P$. gaudichaudianum and Piper sp. were available, in order of abundance. Even though $P$. amalago was the most widely available species, it was the 
Table I. Phenology of Piper species in PMAT, based on the existing species in the transections marked in the tracks, and on the newspaper placed inside the colony of Carollia perspicillata to collect feces between the months of October 2001 and September 2002.

\begin{tabular}{|c|c|c|c|c|c|c|c|c|c|c|c|c|}
\hline \multirow{2}{*}{ Plant species } & \multicolumn{12}{|c|}{ Months (2001-2002) } \\
\hline & Oct & Nov & Dec & Jan & Feb & Mar & Apr & May & Jun & Jul & Aug & Sep \\
\hline Piper aduncum & pes & pes & pepts & + & 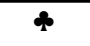 & * & * & $\bullet$ & $\bullet$ & $*$ & 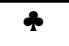 & 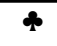 \\
\hline Piper amalago & Appep & tept & peptep & \& & 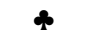 & \& & * & \& & * & 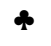 & $\bullet$ & 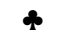 \\
\hline Piper crassinervium & - & - & $\bullet$ & pepts & epeps & - & - & - & - & - & - & - \\
\hline Piper gaudichaudianum & - & ets & - & $\bullet$ & $\bullet$ & pesp & \& & 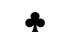 & $\&$ & $\bullet$ & 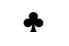 & - \\
\hline Piper sp. & + & + & + & $\diamond$ & \& & 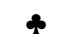 & - & $\Delta$ & * & * & + & * \\
\hline
\end{tabular}

(\$) Ripe infrutescences per 0,04 ha: (\$) 1 to 6 , (\$\$) 7 to 15, and (\$\$) 15 or more; $\left({ }^{*}\right)$ seeds found inside the colony; ( $\$$ ) inflorescences; $(-)$ absence of infrutescences and inflorescences.

third most highly consumed item while P. aduncum and Piper sp. were the most highly consumed species by C. perspicillata.

In the summer of 2002 (Fig. 4), in January, P. crassinervium was widely available in opposition to $P$. aduncum, but the proportion of the consumption of these items was similar. In February, $P$. crassinervium was widely available, and so was $P$. amalago. These two items were consumed proportionally to their availability, but $P$. aduncum was also consumed, despite not being amongst the items available in the transects. At the end of the summer, the most available Piper species was $P$. gaudichaudianum, followed by Piper sp. and P. amalago; the most highly consumed item was P. gaudichaudianum.

In the fall (Fig. 5), in April, only P. gaudichaudianum was available in the transects, and it was highly consumed. However, $P$. amalago was also consumed, but in smaller proportions. In May, in a decreasing order of abundance, P. amalago, $P$. gaudichaudianum and Piper sp. were available, $P$. gaudichaudianum being the most highly consumed species. At the end of this season, only $P$. gaudichaudianum was available in the transects, in a small amount, but its consumption was high. Yet, P. amalago and Piper sp. were also found among the ingested items.

During the winter (Fig. 6), in July, P. amalago and P. gaudichaudianum were available in the transects. However, the items that were most highly consumed were Piper sp. and $P$. aduncum; the consumption of $P$. amalago was considerably low. In August, Piper sp. and $P$. aduncum infrutescences were available in the same quantity in the transects; P. gaudichaudianum infrutescences were also available, but in a lower quantity. The most highly consumed species was Piper sp., followed by $P$. gaudichaudianum, and $P$. aduncum was nearly not consumed at all. At the end of the winter, only $P$. aduncum was available in the transects, but $P$. amalago and Piper sp. were found in the diet of $C$. perspicillata as well.

The quantity of infrutescences available in the transects and what was ingested by the bats of the colony throughout the year show that $P$. amalago and $P$. aduncum were the most abundant species, although $P$. amalago was among the species of lowest consumption. P. aduncum and P. gaudichaudianum were the most commonly ingested species (Figs 3-6).

The analysis of physio-chemical values of infrutescences of the Piper species collected in the tracks shows only a trend of these values, due to the fact that they were collected in different periods and from different individuals (Tab. II). P. amalago presented the lowest percentage of lipids and the lowest total calorific value, and Piper sp. the highest values. It was not possible to determine the percentage of carbohydrates, proteins and total calorific value of $P$. crassinervium due to the low number of ripe infrutescences found in the transects for analysis.

\section{DISCUSSION}

The methodology used does not offer conditions to determine the quantity of food consumed by Carollia perspicillata during the whole night because, according to Fleming (1988), it can cover long distances in its search for food, use temporary night roosts near the feeding area for short breaks and eat the ripe Piper plants found. Moreover, it may remain in the same area for a long period, returning to the day roost only at the end of the night. However, this methodology allows us to identify and quantify the items utilized in its diet in the moment that precedes the return of the animals to its roost through the feces found.

During the spring, C. perspicillata ingested a larger quantity of one of the least available species in the transects, Piper aduncum, and not the most abundant one, P. amalago. This higher consumption of $P$. aduncum may be related to the nutritional differences of the infrutescences, once the comparison of the physio-chemical composition of the two species revealed that $P$. aduncum had a larger quantity of lipids and a higher calorific value than P. amalago. This reinforces PIANKA (1982), who claims that any consumer prefers to save energy by finding food that is worth a higher quantity of energy per unit of consumption.

During the summer, there was a greater search for more abundant species, such as $P$. crassinervium in January and February and $P$. gaudichaudianum in March, which could be justified, in the first case, by the fact that in addition to its abundance, $P$. crassinervium presented a quantity of lipids higher than all the other Piper species available in the transects. According to WENDELN et al. (2000), the consumption of abun- 

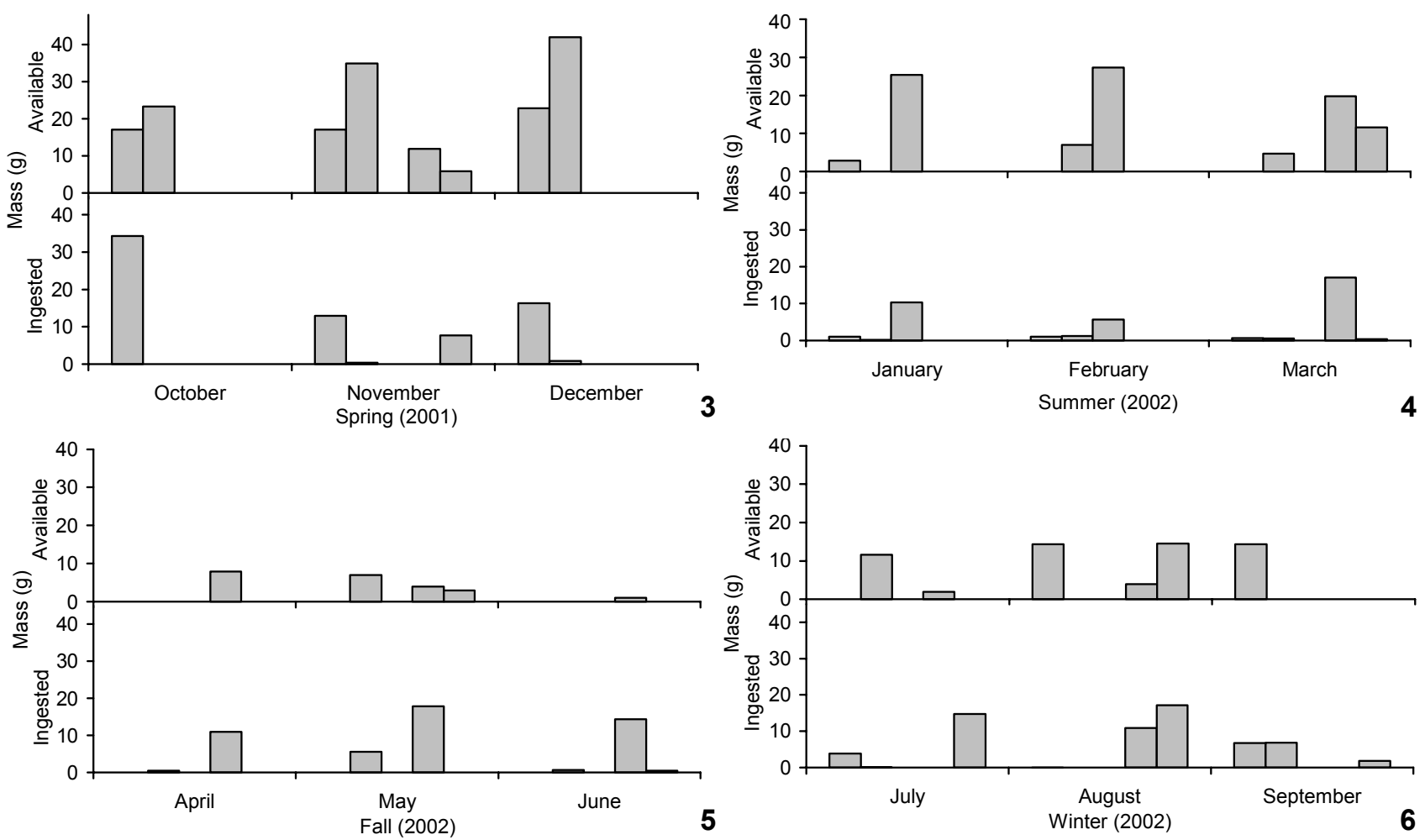

Figures 3-6. Quantity of Piperaceae mass found in the sample transects (0,04 ha/month) and quantity ingested by the colony of Carollia perspicillata studied during the: (3) spring, (4) summer, (5) fall, and (6) winter in the Parque Municipal Arthur Thomas.

Table II. Physio-chemical analysis and average of total mass of Piper infrutescences consumed by Carollia perspicillata in Parque Municipal Arthur Thomas from October 2001 to September 2002.

\begin{tabular}{|c|c|c|c|c|c|c|c|c|c|}
\hline \multirow[b]{2}{*}{ Plant species } & \multicolumn{4}{|c|}{ Physio-chemical characteristics } & \multicolumn{5}{|c|}{ Total mass of infrutescence } \\
\hline & $\mathrm{N}_{1}$ & $\begin{array}{c}\text { Carbohydrates } \\
\text { (\%) }\end{array}$ & $\begin{array}{l}\text { Lipids } \\
\text { (\%) }\end{array}$ & $\begin{array}{l}\text { Gross protein } \\
\text { total } \mathrm{N}_{2}(\%)\end{array}$ & $\begin{array}{l}\text { Calorific value } \\
(\mathrm{Kcal} / 100 \mathrm{~g})\end{array}$ & $\mathrm{N}_{2}$ & $\begin{array}{l}\text { Average } \\
\text { (g) }\end{array}$ & SD & VC \\
\hline P. aduncum & 35 & 18.59 & 1.46 & 3.25 & 100.50 & 10 & 3.47 & 0.46 & 13.25 \\
\hline P. amalago & 40 & 18.12 & 0.53 & 3.65 & 91.85 & 21 & 3.02 & 0.70 & 23.17 \\
\hline P. crassinervium & 12 & ND & 1.68 & ND & ND & 12 & 2.41 & 0.47 & 19.54 \\
\hline P. gaudichaudianum & 45 & 18.14 & 1.29 & 4.79 & 103.33 & 12 & 2.39 & 0.46 & 19.24 \\
\hline Piper sp. & 30 & 21.66 & 2.41 & 5.56 & 130.57 & 10 & 3.52 & 0.73 & 20.73 \\
\hline
\end{tabular}

(N1) number of ripe infrutescences collected for the determination of their physio-chemical characteristics; (N2) number of ripe infrutescences collected for the determination of the mass average; (ND) not determined; (SD) standard deviation; (VC)= variation coefficient.

dant items with a higher calorific value provides the bat with a higher energetic return. In March, although Piper sp. was available in the transects and presented a high calorific value and the highest quantity of lipids of all Piper species, it was not highly consumed, which may be explained by the average mass of infrutescences available, as P. gaudichaudianum was 32\% lighter than Piper sp. The fact that $C$. perspicillata consumed the lightest and most abundant item may indicate energy saving concerning the search for and transport of this plant species, even in the presence of a potentially more energetic one. According to Delorme \& Thomas (1999), in places where food is abundant, the individuals can be more selective and limit their diet to the best food types.

During the fall, in April and June, when only P. gaudichau- 
dianum infrutescences were available in the transects, other Piper species were consumed in a lower quantity, indicating that the bats searched for food outside the transects and/or tracks, confirming data obtained by CourTs (1988), who suggests that European frugivorous bats search for alternative food sources when they are scarce. Some species can even search for unripe fruits to supply their nutritional needs (NeLSON et al. 2000). The greater search for $P$. gaudichaudianum, which had infrutescences available in the transects during the month of May, may be related to its better energetic quality when compared to P. amalago, the most abundant species as, according to PIANKA (1982), when there are distinct types of food available the search is for the most calorific items. This justifies the energetic gain, since the quality of the food is as important as the quantity (ODum 1988).

During the winter, in July, C. perspicillata preferred to feed on Piper sp., indicating the search for this item outside the transects and/or tracks, a fact which could be related to the better content of energetic substances in this plant species when compared to the others available in the transects. According to WENDELN et al. (2000), the ingestion of more energetic food compensates for the effort made during the search for it. In August, there was a greater search for Piper sp. and P. gaudichaudianum, which supports the idea of a greater consumption of the most calorific food items when various species are in frutification, agreeing with what is suggested by PIANKA (1982) and WENDELn et al. (2000). At the end of the winter, when food was scarcer in the transects, $C$. perspicillata also consumed $P$. aduncum, the only Piper available in them, and also Piper species outside the transects and/or tracks, even those with a lower calorific value. Some bats complemented their diet with food items available in low quantities (Ruby et al. 2000) and with a low calorific value (Elangovan \& Marimuthu 2001). In this study, C. perspicillata did not discard the species available in smaller amounts.

In addition to the factors that lead bats to choose their food and the importance of the fruit mass for this choice, FLEMING $(1986,1988)$ suggests that they are potentially influenced by extrinsic factors, like ambient light level (related to the risk of predation), the time-space abundance of the fruits, their nutritional characteristics, size and availability, and by intrinsic factors, which comprise the size of the animal, its reproductive status and social position.

It was observed that in PMAT the variation of the infrutescence abundance throughout the year and the nutritional characteristics of each species influenced C. perspicillata on its food choice. In addition to that, the collections were carefully carried out always in the period of new moon with the aim of minimizing the influence of the light, since this species presents lunar phobia (FLEMING 1988).

According to Pereira et al. (1995), bats can carry the entire fruit to perches depending on the size and mass of the fruit. Bizerril \& RAW (1988) have observed C. perspicillata biting pieces of Piper arboreum infrutescences because they could not carry the whole fruit. In PMAT the entire infrutescences were carried because the discarded stems were found inside the colony and on the newspaper utilized for the collection of feces, indicating that the mass of the Piper species had little influence on the food choice.

The PMAT, with its 66 ha of unspoiled native area, has proved to be a safe shelter for some bat species (Felix et al. 2001), such as Myotis ruber, which is threatened with extinction (Aguiar et al. 1998), and for other animals which depend on the food found in the park. Therefore, more effort should be made for its conservation and preservation.

In this study five species of Piper were found in PMAT: $P$. aduncum, $P$. amalago, $P$. crassinervium, $P$. gaudichaudianum and Piper sp. The results show that in the park, the preferences of $C$. perspicillata are related to the greater abundance or the higher energetic value of the available species. The greater search for the most energetic and least abundant species, which occurred in the spring and winter, is related to the energetic gain, that is, the species searches for food that is worth a higher quantity of energy per unit of consumption; and the greater search for the most abundant species, which occurred in the summer and fall, is related to the energy saved in the search for food.

\section{ACKNOWLEDGEMENTS}

We would like to thank Paulo C. Dolibaina from Autarquia Municipal do Ambiente (AMA) for allowing us to carry out this study in Parque Municipal Arthur Thomas; Professor Ana O.S. Vieira (Herbarium FUEL), for helping us identify the plant material; Professor Raúl J.H.C. Goméz (Analysis Laboratory TAM), for the physio-chemical analysis of the infrutescences; all the staff of the Plant Ecophysiology Laboratory for allowing us to use the semi-analytic scale. To Proap/CAPES for the financial resources.

\section{REFERENCES}

Aguiar, L.M.S.; R.B. Machado; M. Zortéa; S.L. Mendes \& A.B. RYLANDS. 1998. Working with the IUCN red list categories: The experience of the workshop on the conservation of brazilian bats. Boletim do Museu de Biologia Mello Leitão (Nova Série), Santa Teresa, 9: 3-11.

Bizerril, M.X.A. \& A. Raw. 1998. Feeding behaviour of bats and the dispersal of Piper arboreum seeds in Brazil. Journal of Tropical Ecology, Cambridge, 14: 109-114.

Charles-dominique, P. 1991. Feeding strategy and activity budget of the frugivorous bat Carollia perspicillata (Chiroptera: Phylostomidae) in French Guiana. Journal of Tropical Ecology, Cambridge, 7: 243-256.

CourTs, S.E. 1998. Dietary strategies of Old World fruit bats (Megachiroptera, Pteropodidae): how do they obtain sufficient protein? Mammal Review, Oxford, 28 (4): 185-193.

Dinerstein, E. 1986. Reproductive ecology of fruit bats and the seasonality of fruit production in a Costa Rican cloud forest. Biotropica, St. Louis, 18 (4): 307-318.

Revista Brasileira de Zoologia 21 (2): 371-377, junho 2004 
Delorme, M. \& D.W. Thomas. 1999. Comparative analysis of the digestive efficiency and nitrogen and energy requirements of the phyllostomid fruit-bat (Artibeus jamaicensis) and the pteropodid fruit-bat (Rousettus aegyptiacus). Journal of Comparative Physiology Biochemical Systemic and Environmental Physiology, Heidelberg, 169 (2): 123-132.

Elangovan, V. \& G. Marimuthu. 2001. Comparative analysis on food, energy and nitrogen intake of a megachiropteran bat, Cynopterus sphinx. Proceedings of the National Academy of Sciences India Section B Biological Sciences, New Delhi, 71 (2): 115-120.

Félix, J.S.; N.R. dos Reis; I.P. de Lima; E.F. Costa \& A.L. Peracchi. 2001. Is the area of the Arthur Thomas Park, with its 82.72 ha, sufficient to maintain viable chiropterian populations? Chiroptera Neotropical, Brasília, 4 (1-2): 129-133.

Figueiredo, R.A. De \& M. Sazima. 2000. Pollination biology of Piperaceae species in southeastern Brazil. Annals of Botany, London, 85 (4): 455-460.

Fleming, T.H. 1986. Opportunism vs. specialization: the evolution of feeding strategies in frugivorous bats. p.105118. In: A. Estrada \& T.H. Fleming (Eds). Frugivores and seed dispersal. Dordrecht, W. Junk Publishers, 392p

ـ 1988. The Short-Tailed Fruit Bat: A Study in PlantAnimal Interactions. Chicago, The University of Chicago Press, 365p.

Garcia, Q.S.; J.P. Rezende \& L.M.S. Aguiar. 2000. Seed dispersal by bats in a disturbed area of southeastern Brazil. Revista Biologica Tropical, San Jose, 48 (1): 125-128.

GARDNER, A.L. 1977. Feeding habitats, p. 293-350. In: R.J. BAKER; J.K. Jones \& D. Carter (Eds). Biology of bats of the new world family Phillostomidae. Part I. Huston, Special Publication Museum Texas Tech University, 350p.

IAPAR. 2002. Boletim meteorológico do Instituto Agronômico do Paraná. Londrina, Iapar.

Instituto Adolfo Lutz. 1976. Normas analíticas do Instituto Adolfo Lutz. Métodos químicos e físicos para análise de alimentos. São Paulo, Instituto Adolfo Lutz, vol. 1, 371p.

MAACK, R. 2002. Geografia física do Estado do Paraná. Curitiba, Imprensa Oficial Paraná, $3^{a}$ ed., 438p.

Marinho-Filho, J. 1991. The coexistence of two frugivorous bat species and the phenology of their food plants in Brazil. Journal of Tropical Ecology, Cambridge, 7: 59-67.

MülLer, M.F. \& N.R. Dos ReIs. 1992. Partição de recursos alimentares entre quatro espécies de morcegos frugívoros (Chiroptera, Phyllostomidae). Revista Brasileira de Zoologia, Curitiba, 9 (3/4): 345-355.

Murphy, D.D. 1997. Desafios à diversidade biológica em áreas urbanas. p.89-97. In: E.O. Wilson (ed.). Biodiversidade. Rio de Janeiro, Nova Fronteira, 657p.

Nelson, S.L.; A.M. Miller; E.J. Heske \& G.C.J. Fahey. 2000. Nutritional quality of leaves and unripe fruit consumed as famine foods by the flying foxes of Samoa. Pacific Science, Honolulu, 54 (4): 301-311
ODum, E.P. 1988. Ecologia. Rio de Janeiro, Guanabara Koogan, $434 \mathrm{p}$.

Pereira, M.V.L.; A.L. Peixoto \& F.R. Di-Maio. 1995. Plantas utilizadas como recurso alimentar pela fauna silvestre na represa de Ribeirão das Lajes, Rio de Janeiro, Brasil. Revista Universidade Rural Série Ciências da Vida, Rio de Janeiro, 17 (2): 25-40.

PiANKA, E.R. 1982. Ecologia evolutiva. Barcelona, Omega, 365p.

Reis, N.R. Dos \& M.F. Müller. 1995. Bat diversity of forest and open areas in a subtropical region of south Brazil. Ecologia Austral, Córdoba, 5: 31-36.

Reis, N.R. dos; A.L. Peracchi; I.P. de Lima; M.L. Sekiama \& V.J. RochA. 1998. Updated list of the chiropterians of the city of Londrina, Paraná, Brazil. Chiroptera Neotropical, Brasília, 4 (2): 96-98.

Reis, N.R. dos; A.L. Peracchi; M.L. Sekiama \& I.P. de Lima. 2000. Diversidade de morcegos (Chiroptera: Mammalia) em fragmentos florestais no estado do Paraná, Brasil. Revista Brasileira de Zoologia, Curitiba, 17 (3): 697-704.

Reis, N.R. dos; M. da S. Barbieri; I.P. de Lima \& A.L. Peracchi. 2003. O que é melhor para manter a riqueza de espécies de morcegos (Mammalia, Chiroptera): um fragmento florestal grande ou vários fragmentos de pequeno tamanho? Revista Brasileira de Zoologia, Curitiba, 20 (2): 225-230.

Ruby, J.; P.T. Nathan; J. Balasingh \& T.H. Kunz. 2000. Chemical composition of fruits and leaves eaten by short-nosed fruit bat, Cynopterus sphinx. Journal of Chemical Ecology, New York, 26 (12): 2825-2841.

Schulze, M.D.; N.E. Seavy \& D.F. Whitacre. 2000. A comparison of the phyllostomid bat assemblages in undisturbed neotropical forest and in forest fragments of a slash-andburn farming mosaic in Peten, Guatemala. Biotropica, St. Louis, 32 (1): 174-184.

TAVARES, V. DA C. 1999. Flight morphology, diet and composition of a bat assemblage (Mammalia: Chiroptera) in the Rio Doce State Parque, south-east Brazil. Chiroptera Neotropical, Brasilia, 5 (1/2): 117-118.

Thies, W.; Kalko, E.K.V. \& H.U. Schnitzler. 1998. The roles of echolocation and olfaction in two neotropical fruit-eating bats, Carollia perspicillata and C. castanea, feeding on Piper. Behavioral Ecology and Sociobiology, Berlin, 42: 397-409.

Wendeln, M.C.; J.R. RunkLE \& E.K.V. KalKo. 2000. Nutritional values of 14 fig species and bat feeding preferences in Panama. Biotropica, St. Louis, 32 (3): 489-501.

Wilson, D.E.; C.F. Ascorra \& T.S. Solari. 1996. Bats as indicators of habitat disturbance, p. 613-625. In: D.E. WILSON \& S.A. SANDOVAL (Eds). MANU - The Biodiversity of southeastern Peru. Washington, Smithsonian Institution Press, 679p.

Received in 12.VIII.2003; accepted in 07.VI.2004.

Revista Brasileira de Zoologia 21 (2): 371-377, junho 2004 